\title{
Profitability Analysis of Tiger Grouper Hatchery (Epinephelus fuscoguttatus) Household Scale in Kelatakan Village, Situbondo, East Java
}

\author{
Mustika Palupi $^{1^{*}}$, Ren Fitriadi ${ }^{1}$, Muh. Sulaiman Dadiono ${ }^{1}$, Rima Oktavia Kusuma ${ }^{1}$ and \\ Danang Yonarta ${ }^{2}$ \\ ${ }^{1}$ Study Program of Aquaculture, Faculty of Fisheries and Marine Science, Jenderal Soedirman \\ University, Dr. Soeparno Street, Karangwangkal, Purwokerto 53122, Indonesia \\ ${ }^{2}$ Study Program of Aquaculture, Faculty of Agriculture. Sriwijaya University. Palembang-Prabumulih \\ Street KM 32, Indralaya, Ogan Ilir, South Sumatera 30662, Indonesia
}

*Correspondence :

mustika.palupi@unsoed.ac.id

Received : 2020-05-22

Accepted : 2021-01-16

Keywords :

Business analysis, Hatchery, Tiger grouper, Investment

\begin{abstract}
The development of tiger grouper cultivation technology has not been maximally implemented so that the survival rate of fish is very low. The result is that it is very vulnerable to losses in cultivation. This study aims to analyze the profitability of tiger grouper hatchery. The research method used is a case study. Primary data is collected through observation, interviews, and questionnaires. Secondary data is data obtained indirectly. The calculated data analysis is the Benefit-Cost (B/C) Ratio, Break-even Point Analysis and Profitability. The results obtained are BEP in units is 170,606 heads and BEP in price is IDR 1,709,750, B/C Ratio is 1.65, and the payback period is 5 years 2 months.
\end{abstract}

\section{INTRODUCTION}

Tiger grouper generally grows faster than other types of grouper (Endrawati et al., 2008; Akbar et al., 2013; Prihadi, 2017). It is estimated that the absolute growth of tiger grouper is 173.97 grams. The grouper is also strong and able to adapt to environmental changes. Tiger grouper is relatively easy to cultivate because it has high adaptability (Rahmawati et al., 2013; Sutarmat and Yudha, 2013).

Tiger grouper marketing continues to grow, especially in Singapore, Hong Kong, Taiwan and Japan. Most of the exported tiger grouper comes from cultivation in ponds or floating marine cage instead of natural catch. Fish rearing is very dependent on seed production; an insufficient supply of seeds will affect the rearing activity. Therefore, knowledge and skills about seed production techniques are necessary to produce high-quality seeds. It is aimed at fulfilling the sustainability of the hatchery up to the rearing of tiger grouper (Sudradjat, 2015).

Tiger grouper trading is a profitable activity since the fish export increased by $350 \%$. In January 2019, the volume of exported live grouper in Indonesia was 277,006 tons. The highest export volume was in March 2019 which a total of 317,874 tons and the lowest export volume was in August 2019 with a total of 99,316 tons. The volume of exported grouper from August to December 2019 has increased every month to reach 205,572 tons at the end of the year (BPS, 2020). This value encourages grouper seed production needed for grouper rearing activities, however, one of the 
obstacles in seed production activities is high-cost feed. It does not hinder the fish farmers since calculating the financial analysis of a business allows them to estimate the financing, the amount of product and the profits.

The largest grouper hatchery center is currently located in Situbondo, East Java, both in terms of the number of hatcheries and the number of productions. In 2018, there were 70 household-scale hatchery units and many Situbondo hatcheries have been included in the registered hatchery list, while the logging business is still limited to around 10 actors, both in fish ponds and fish tub (Andarwati, 2020). The current problem is the unknown condition of hatchery business in the research area, observed from the analysis of financial feasibility of hatchery business including calculation of Benefit-Cost Ratio, Breakeven Point Analysis, and Profitability. This study aims are analyzing the financial feasibility of the grouper hatchery business in the study area.

\section{METHODOLOGY}

\section{Place and Time}

This study was conducted in February 2019 in Pecaron Hamlet, Klatakan Village, Panarukan District, Situbondo, East Java.

\section{Research Materials}

The equipment used were seed hatchery tub, seawater reservoir, Branchionus plicatilis culture tub, Nannochloropsis oculata culture tub, plastic drum, dipper, bucket, refractometer, thermometer, sieve, filter bag, ruler, aeration stone, lead ballast, regulator hose, PVC pipe, measuring cup, submersible pump and freezer.

The materials used were Nannochloropsis oculata phytoplankton; Branchionus plicatilis zooplankton; Artemia salina cysts; Scott Emulsion; artificial feed; squid oil; urea, TSP and ZA fertilizers; rebon shrimp and vitamin $\mathrm{C}$.

\section{Research Design}

Data of the study were collected using the survey method; in this case, the study was carried out by following and analyzing all activities in the research location related to the production of tiger grouper seeds and the financial calculation. The data used were primary and secondary data. Primary data were obtained from direct observation, while secondary data were obtained from interviews with technicians and staff as well as literature studies on tiger grouper (Epinephelus fuscoguttatus) hatchery (Sugiyono, 2002). There were 8 respondents (technicians and staff) who were interviewed.

\section{Work Procedure}

\section{Preparation of Containers and Cultivation Media}

The containers used in the production of tiger grouper seeds were larvae rearing tubs, seed rearing tubs and natural feed culture tubs. The tubs were dried for 2 weeks, and then the wall and the bottom of the tubs were flushed with 3 liters of chlorine solution dissolved in 12 liters of freshwater. The equipment such as regulator hoses, leads ballast, aeration stones, tub covers plastics and filter bags were soaked in the same dose of Chlorine solution in the feed drum.

\section{Natural Feed Provision}

Mass culture of phytoplankton was carried out in a natural feed culture tub. 2 $\mathrm{m}^{3}$ of Nannochloropsis oculata was filled into the culture tub with a density of 17 20 million cells/ml, which had previously been added with $8 \mathrm{~m}^{3}$ of seawater and continued by fertilizer application. The fertilizers used were urea 40 ppm, ZA 30 ppm, and TSP 20 ppm. Firstly, TSP was crushed and dissolved in water; it was then put into the culture water. Cultivation was completed in 6-7 days until the phytoplankton were harvested; harvesting was performed by flowing the culture media into the cultivation tub using a 2-inch hose. 


\section{Eggs Spreading and Hatching}

Bags containing the tiger grouper eggs, transported from the hatchery, were drenched with fresh water then floated on the tub surface for 10 minutes. The bags were opened; the eggs were released and spread to the water surface. Each bag contained 100.000 tiger grouper eggs and 200.000 eggs were released into each tub. In D2 (2 days old), the number of eggs in the cultivation tub was counted. Calculation of the hatched eggs was performed by sampling using a 0.5 meters long 2-inch PVC pipe. The pipe was inserted into the tub and the bottom of the tub was covered with the researcher's palm; then the number of larvae entering the pipe was counted. Sampling was carried out in three tubs and four sample points. It aims to determine the Hatching Rate (HR) of the tiger grouper eggs.

\section{Squid Oil Application}

Squid oil was applied during the larvae rearing period. It was applied to the 1-10 days old larvae, with a dose of 0.3 ppm for each application. Squid oil was sprayed at the aeration points to accelerate spreading. This activity was performed three times a day at 06.00, 12.00 and 18.00 .

\section{Larvae Harvest}

Larvae reared for 35 days were harvested; however, few of them were left in the tub. $80 \%$ of water in the rearing tub was removed. The larvae were collected manually using a serving hood and filtered according to the sieve size i.e., $2 \mathrm{~cm}, 2.3$ $\mathrm{cm}$ and $2.5 \mathrm{~cm}$. Larvae in the range of $2-$ $2.5 \mathrm{~cm}$ long were directly transported to the seed rearing room. While those under $2 \mathrm{~cm}$ long were kept in the larvae rearing room. Harvesting was carried out in 10 larvae rearing tubs at 8 a.m. The larvae had been fed with artificial feed and rebon shrimp.

\section{Harvest and Transport}

Seeds were harvested when they were at D45 - D50. Firstly, seeds were sorted based on the adequate harvest size namely $2.5 \mathrm{~cm}, 2.7 \mathrm{~cm}$ and $3 \mathrm{~cm}$, but the seeds were previously collected in the serving hood. For the transport or seeds delivery, $2.5-3.5 \mathrm{~cm}$ seeds were collected in the serving hood with a density of 400800 individuals. They were put in the serving hood inside a tub covered with black tarpaulin and were not fed for 24 hours. Packing was done by preparing seawater with a temperature of $26^{\circ} \mathrm{C}$.

\section{Data Analysis}

Data of the study were analyzed by assessing the investment feasibility of the fish hatchery business in Situbondo using financial analysis. Quantitative data contains the costs needed for running a fish hatchery business, including the investment and operational costs as well as the revenue of the fish seed sale. According to Afero et al. (2010), the criteria used to assess the investment feasibility of fish hatchery Business are Benefit-Cost Ratio, Break-Even Point and Profitability.

\section{RESULTS AND DISCUSSION Investment}

Investment is capital required for the procurement of physical materials or equipment, and the capital will be bound into assets. Investment in a business is an allocation of funds including the use of funds for the procurement of facilities and infrastructures (Sudarsono and Sudjiharno, 1998). The investment cost for the business of tiger grouper seeds production was IDR $371,115,000$. At the beginning of business development, the investment was expended for the procurement of production facilities comprising construction, purchase of land and equipment necessary for the production of tiger grouper seeds. The table of investment cost calculation for the activity of tiger grouper aquaculture can be seen as follows. 
Table 1. Investment costs.

\begin{tabular}{|c|c|c|c|c|c|c|}
\hline No & Type & $\begin{array}{l}\text { Number } \\
\text { (unit) }\end{array}$ & $\begin{array}{l}\text { Unit Price } \\
\text { (IDR) }\end{array}$ & $\begin{array}{l}\text { Amount } \\
\text { (IDR) }\end{array}$ & $\begin{array}{c}\text { Technical } \\
\text { Age }\end{array}$ & $\begin{array}{l}\text { Depreciation } \\
\text { (IDR) }\end{array}$ \\
\hline 1 & Land & 1 & $100,000,000$ & $100,000,000$ & - & 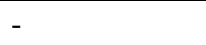 \\
\hline 2 & Building & 1 & $200,000,000$ & $200,000,000$ & 20 & $10,000,000$ \\
\hline 3 & Hi-blow & 2 & $3,600,000$ & $7,200,000$ & 5 & $1,440,000$ \\
\hline 4 & Sea water pump 4" & 2 & $5,000,000$ & $10,000,000$ & 5 & $2,000,000$ \\
\hline 5 & Fresh water pump & 2 & $2,000,000$ & $4,000,000$ & 4 & $1,000,000$ \\
\hline 6 & Submersible pump 1" & 1 & $1,500,000$ & $1,500,000$ & 3 & 500,000 \\
\hline 7 & Electrical installation & 1 & $5,000,000$ & $5,000,000$ & 5 & $1,000,000$ \\
\hline 8 & Aeration installation & 1 & 500,000 & 500,000 & 5 & 100,000 \\
\hline 9 & Water installation & 1 & 500,000 & 500,000 & 5 & 100,000 \\
\hline 10 & Genset & 1 & $10,000,000$ & $10,000,000$ & 10 & $1,000,000$ \\
\hline 11 & Refrigerator & 1 & $1,000,000$ & $1,000,000$ & 5 & 200,000 \\
\hline 12 & Motorcycle & 1 & $6,000,000$ & $6,000,000$ & 5 & $1,200,000$ \\
\hline 13 & Car & 1 & $20,000,000$ & $20,000,000$ & 5 & $4,000,000$ \\
\hline 14 & Drum 200 liter & 10 & 150,000 & $1,500,000$ & 5 & 300,000 \\
\hline 15 & Drum 75 liter & 3 & 80,000 & 240,000 & 5 & 48,000 \\
\hline 16 & Refractometer & 1 & $2,000,000$ & $2,000,000$ & 5 & 400,000 \\
\hline 17 & Thermometer & 2 & 50,000 & 100,000 & 2 & 50,000 \\
\hline 18 & Hose 1,5 “ & 20 & 3,000 & 60,000 & 2 & 30,000 \\
\hline 19 & Spiral Hose & 3 & 5,000 & 15,000 & 2 & 7,500 \\
\hline 20 & Hatchery equipment & 1 & $1,000,000$ & $1,000,000$ & 2 & 500,000 \\
\hline 21 & Mechanical filter & 1 & 500,000 & 500,000 & 5 & 100,000 \\
\hline \multicolumn{2}{|c|}{ Total } & & & $371,115,000$ & & \\
\hline
\end{tabular}

The amount of total investment in grouper fish hatchery varies from place to place and cycle. Mahyuddin (2008) stated that the amount of investment capital in fish farming varies greatly depends on the type of fish farming. Total investment is the sum of fixed capital and working capital or variable capital. The total investment invested by each fish farmer. The amount of fixed capital and working capital incurred will affect the investment put in. The amount of money invested by the fish farmer will affect the investment return period.

\section{Costs}

The costs used in supporting this activity are divided into two groups, namely fixed costs and variable costs. Fixed costs are expenditures in which the amount is fixed, independent of changes in the level of activity in producing outputs or products within certain intervals. Cost is considered to be fixed in terms of the amount of cost rather than the cost per unit. Fixed costs greatly affect the residual value (Winanto, 2004). Fixed costs usually include depreciation, salary, insurance, rent, maintenance, and other indirect costs (Sudarsono and Sudjiharno, 1998). Variable costs are the costs which value always changes according to production volumes such as rearing cost, operating equipment and other equipment (Winanto, 2004).

In the grouper hatchery studied, fixed costs include depreciation costs, equipment costs, employee salary, electricity, telephone as well as land and building tax. The total amount of fixed costs in a year is IDR $170,975,500$. Variable costs include eggs, feed, medicines, fertilizers and several materials used in seed production activities, which vary in value according to the volume of production. The amount of variable costs during one production cycle is IDR $44,151,000$ or IDR $265,506,000$ per year. One cycle of grouper hatchery is for 3 months.

\section{Profit/Loss Analysis}

Soeharto (1997) stated that profit or loss analysis is the amount of income 
resulted after deducted by fixed costs and variable costs. Profit/loss analysis generated per cycle is as follows:

Total sales $=$ number of seeds sold in one cycle $\mathrm{x}$ retail price

$=120,000$ head $\mathrm{x}$ IDR 1000

$=$ IDR $120,000,000 /$ cycle

Calculation of profit/loss analysis during one cycle is as follows:

$=$ Total sales - total costs

$=$ Total sales - (fixed costs + variable costs)

$=$ IDR 120,000,000 - (IDR 28,495,916 +

IDR 44,151,000)

$=$ IDR $120,000,000-$ IDR 72,649,916

$=$ IDR 47,353,084

The difference between total sales and total costs showing positive results indicates that the business is profitable. The profit can be increased by increasing product yields or reducing operating costs; or doing both, i.e., increasing product yields and reducing operating costs (Jannah, 2018).

\section{Break-even Point}

Break-even point is a point when the business reaches a break-even (not getting profit nor loss). BEP calculation can be seen from two factors, namely price BEP and production BEP (Winanto, 2004). According to Sudarsono and Sudjiharno (1998), BEP which is also known principal return analysis aims to find out how many businesses run in order not to suffer losses. Break-even point in which the business does not get profit or loss is as follows:

BEP in unit

$=$ fixed cost per year : selling price per unit- (variable cost per year : amount produced per year)

$=$ IDR $170,975,000$ : IDR 1,000-(IDR

$265,506,000: 720,000$ )

$=170,606$ heads

The unit produced in which the business does not get profit or loss was 170,606 heads per year. Break-even point in which the business does not get profit or loss when the seeds are sold at price as follows:

$$
\begin{aligned}
\mathrm{BEP} \text { in price } & =\frac{\text { fixed cost per year }}{1-\left(\frac{\text { variable cost per year }}{\text { annual sales }}\right)} \\
& =\frac{170,975,000}{1-\left(\frac{265,506,000}{720,000,000}\right)} \\
& =\operatorname{IDR~} 1,709,750,000
\end{aligned}
$$

BEP price or unit minus the amount will increase the company profit. It can be done by increasing annual sales result or reducing variable costs, so that the profit increases (Mulyadi, 2001).

\section{B/C Ratio}

The calculation is emphasized more on the investment criteria which the measurement is directed at comparing, measuring and calculating the profit level of fishery business. B/C value can identify the feasibility of a business; if the value is 1 , it means that the business is not considered profitable, therefore it needs improvement. The smaller the $\mathrm{B} / \mathrm{C}$ value, the more likely the company will suffer loss. A business is considered feasible when the $\mathrm{B} / \mathrm{C}$ ratio is more than 1 . The smaller the ratio value, the more likely the company will suffer loss (Rausin et al., 2001). Calculation of $B / C$ ratio in the financial analysis is as follows:

$\mathrm{B} / \mathrm{C}=$ total income/total cost

$$
\begin{aligned}
& =\text { IDR 120,000,000/IDR 72,646,916 } \\
& =1.65
\end{aligned}
$$

The result of the $\mathrm{B} / \mathrm{C}$ ratio calculation is $>1$ so that the business is feasible to continue. It is in line with the opinion of Rausin et al. (2001) that B/C ratio which is $>1$ is feasible to continue. The increasing $\mathrm{B} / \mathrm{C}$ ratio value indicates that the profit of seed production is feasible and able to be continued.

\section{Payback Period}

Payback Period (PP) analysis is a period required to recoup the investment expenditures (initial cash investment) using cash flow, in other words, the Payback Period is a ratio between initial cash investment and cash inflow which results in a time unit (Afero et al., 2010). This ratio value is compared with the maximum acceptable payback period 
(Soeharto, 1997). Calculation of payback period for grouper seed production is as follows:

$$
\begin{aligned}
\text { PP } & =\frac{\text { investment }}{(\text { profit }+ \text { depreciation })} \times 1 \text { year } \\
& =\frac{\text { IDR } 37,115,000}{(\text { IDR } 47,353,084+\text { IDR 23,975,500) }} \times 1 \text { year } \\
& =5.2 \text { years }=5 \text { years and } 2 \text { months }
\end{aligned}
$$

The calculation of the Payback Period results in 5 years and 2 months for returning the business investment capital. A faster payback period might be obtained by increasing the profit of the seeds sale.

\section{CONCLUSION}

It can be concluded that the tiger grouper hatchery is feasible. This is based on the result of financial analysis as follows: profit of IDR 47,353,084 per cycle; BEP in unit is $265,506,000$ heads; BEP in unit is IDR 170,606 and BEP in price is IDR $1,709,750,000$; $\mathrm{B} / \mathrm{C}$ Ratio is 1.65 , and Payback Period is 5 years 2 months.

\section{ACKNOWLEDGMENT}

We would like to thank all those who have helped in completing this study.

\section{REFERENCES}

Afero, F., Miao, S. and Perez, A.A., 2010. Economic analysis of tiger grouper Epinephelus fuscoguttatus and humpback grouper Cromileptes altivelis commercial cage culture in Indonesia. Aquaculture international, 18(5), pp.725-739. ht tps://doi.org/10.1007/s10499-0099295-X

Akbar, S., Marsoedi, Soemarno and Kusnendar, E., 2013. Pertumbuhan benih kerapu macan pada fase pendederan dengan kepadatan berbeda di keramba jaring apung (KJA). Teknologi pangan: Media informasi dan komunikasi ilmiah teknologi pertanian, 5(1), pp.3-10. https://doi.org/10.35891/tp.v5i1.4 97

Andarwati, S., 2020. Implementasi program pembibitan kerapu (studi di dinas perikanan Kabupaten Situbondo). Prosiding simposium nasional: Tantangan penyelenggaran pemerintahan di era revolusi industri 4.0. https://doi.org/10.22219/PSNI P.VolO.No0.II|1256-1272

BPS Badan Pusat Statistik, 2020. Nilai ekspor kerapu hidup Indonesia. Website. www.bps.go.id.

Endrawati, H.A., Zaenuri, M.A., Kusdiyantini, E.P. and Kusumaningrum, H.P., 2008. Pertumbuhan juvenil ikan kerapu macan (Epinephelus fuscoguttatus) yang dipelihara dengan padat penebaran berbeda. ILMU KELAUTAN: Indonesian Journal of Marine Sciences, 13(3), pp.133-138. https://doi.org/10.14710/ik.ijms.1 3.3.133-138

Jannah, M., 2018. Analisis pengaruh biaya produksi dan tingkat penjualan terhadap laba kotor. Banque Syar'i: Jurnal Ilmiah Perbankan Syariah, 4(1), $\quad$ pp.87-112. http://dx.doi.org/10.32678/bs.v4i1 .1073

Mulyadi, 2001. Akuntansi manajemen. Penerbit Salemba Empat. Jakarta.

Prihadi, D.J., 2017. Pengaruh jenis dan waktu pemberian pakan terhadap tingkat kelangsungan hidup dan pertumbuhan kerapu macan (Epinephelus fuscoguttatus) dalam karamba jaring apung di Balai Budidaya Laut Lampung. Jurnal Akuatika, 2(1), pp.1-11. http://jour nal.unpad.ac.id/akuatika/article/vi ew/493

Rahmawati, I.Y., Anggoro, S. and Rudiyanti, S., 2013. Domestikasi ikan kerapu macan (Epinephelus fuscoguttatus) melalui optimalisasi media dan pakan. Management of Aquatic Resources Journal (MAQUARES), 2(3), pp.119-127. https://doi.org/10.14710/marj.v2i 3.4193

Rausin, N., Soedarsono, A. and Aditya T.W., 2001. Analisa usaha pembesaran kerapu macan, kerapu 
bebek, di keramba jaring apung. Ditjenkan, BBL Lampung.

Soeharto, 1997. Manajemen proyek dari konseptual sampai operasional. Erlangga. Jakarta.

Sudarsono dan Sudjiharno. 1998. Analisa usaha skala menengah. Direktorat Jendral Perikanan. Jakarta.

Sudradjat, A., 2015. Budidaya 26 komoditas laut unggul. Penebar Swadaya. Jakarta.

Sugiyono, 2002, Statistika untuk penelitian. Penerbit Alfabila. Bandung. 306 p.

Sutarmat, T. and Yudha, H.T., 2013. Analisis keragaan pertumbuhan benih kerapu hasil hibridisasi kerapu macan (Epinephelus fuscoguttatus) dengan kerapu kertang (Epinephelus lanceolatus) dan kerapu batik (Epinephelus microdon). Jurnal Riset Akuakultur, 8(3), pp.363-372. https://doi.org/1 0.15578/jra.8.3.2013.363-372

Winanto, 2004. Memproduksi benih tiram mutiara. Jakarta. Penebar Swadaya 